\title{
Hubungan Sikap Terhadap Seksual Pranikah dengan Tingkat Penilaian Moral Mahasiswa Universitas Al Azhar Indonesia
}

\author{
Eny Suwarni ${ }^{1}$, Radhiya Bustan ${ }^{2}$ \\ ${ }^{1,2}$ Program Studi Psikologi, Fakultas Psikologi dan Pendidikan, Universitas Al-Azhar Indonesia, \\ Jl.Sisingamangaraja, Kompleks Masjid Agung Al Azhar, Kebayoran Baru, Jakarta 12110
}

Penulis untuk Korespondensi/Email: enysuwarni@uai.ac.id

Abstrak - Penelitian ini bertujuan untuk memperoleh gambaran hubungan antara sikap terhadap seksual pranikah dengan tingkat penilaian moral mahasiswa. Jenis penelitian ini adalah korelasional, dengan subjek penelitian 50 orang mahasiswa UAI yang diambil secara accidental sampling. Alat ukur penelitian menggunakan model dari Likert, dan data yang diperoleh dianalisis dengan Pearson's correlation. Hasil penelitian menunjukkan tidak terdapat hubungan yang signifikan antara sikap terhadap seksual pranikah dengan tingkat penilaian moral pada mahasiswa dengan nilai $r \quad .072$. Tidak terdapat hubungan yang signifikan antara sikap terhadap seksual pranikah dengan tingkat penilaian moral prakonvensional dengan $r$ .115. Tidak terdapat hubungan yang signifikan antara sikap terhadap seksual pranikah dengan tingkat penilaian moral konvensional dengan $r .053$. Tidak terdapat hubungan yang signifikan antara sikap terhadap seksual pranikah dengan tingkat penilaian moral pascakonvensional dengan $r$-.072. Tetapi hasil perbedaan mean dari variabel sikap terhadap seksual pranikah, pada aspek kognitif sebesar 92.96. aspek afektif 81.32. dan aspek konatif 61.68. Artinya unsur kognitif atau pemikiran lebih dominan ketika mereka diminta untuk bersikap terhadap seksual pranikah. Tingkat penilaian moral mahasiswa lebih tinggi pada tahap konvensional (35.34) dibandingkan dengan tahap prakonvensional (22.24) dan pasca konvensional (12). Artinya mahasiswa dapat menginternalisasi standar dari figur otoritas, mereka peduli dan dapat mempertahankan aturan sosial jika dihadapkan pada penilaian moral terhadap seksual pranikah. Saran yang dapat diberikan dari hasil penelitian ini adalah mahasiswa perlu lebih banyak diajak diskusi dan menalar untuk meningkatkan pengetahuan bagaimana bersikap terhadap seksual pranikah, agar mereka dapat menegakkan aturan agama, aturan hukum dan aturan sosial disaat mereka menjalin hubungan dengan lawan jenis. Pihak universitas maupun orang tua dapat membuat program bersama yang dapat menstimulasi penilaian moral mahasiswa dengan memberikan perhatian yang lebih tentang bagaimana seharusnya mahasiswa menilai sikap terhadap seksual pranikah. Aturan yang diterapkan dikampus, perlu diterapkan juga di saat mereka berada di rumah agar penilaian moral mereka terhadap sikap pada seksual pranikah menjadi lebih baik dan mengurangi perilaku yang mengarah pada seksual pranikah. Selain itu untuk meningkatkan penilaian moral terhadap seksual pranikah pihak universitas dapat bekerjasama dengan insitusi terkait misalnya BKKBN, dengan membuat program edukasi dikampus tentang bahaya penyimpangan perilaku seksual pranikah

Kata Kunci - Sikap terhadap seksual pranikah, Tingkat penilaian moral prakonvensional, Konvensional dan pasca konvensional

Abstract - This study aimed to obtain the relationship between attitudes toward premarital sexual with moral assessment level students. This type of research is correlational, with research subjects 50 students of UAI taken by accidental sampling. Measuring instrument studies using models of Likert, and the data were analyzed by Pearson's correlation. The results showed no significant correlation between attitudes toward premarital sexual with the level of moral judgments in students the value of $\mathbf{r} \mathbf{. 0 7 2}$. There is no significant relationship between attitudes 
toward premarital sexual with the level of pre-conventional moral judgments with $r .115$. There is no significant relationship between attitudes toward premarital sexual with conventional levels of moral judgment with $\mathbf{r} \mathbf{. 0 5 3}$. There is no significant relationship between attitudes toward premarital sexual level moral judgments post-conventional with $\mathbf{r} \mathbf{- . 0 7 2}$. But the results of the mean difference of the variable attitudes toward premarital sex, on cognitive aspects of 92.96. 81.32 affective aspects. and conative aspects 61.68. That is an element of cognitive or thinking more dominant when they are asked to act against premarital sex. The level of moral judgments of students was higher in conventional stage (35.34) compared with prakonvensional stage (22:24) and conventional post (12). This means that students can internalize the standards of authority figures, they care and can maintain social rules when faced with moral judgments against premarital sex. Advice can be given on the results of this study are students need more invited to discuss and make sense to increase the knowledge of how to behave towards sex before marriage, so that they can enforce the rules of religion, rule of law and social rules when they are in a relationship with the opposite sex. The university and parents can create together a program to stimulate the moral assessment of students by providing more attention on how to assess student attitudes toward premarital sexual. Rules are applied campus, need to apply also when they are at home so that their moral assessment of the attitudes on premarital sexual getting better and reduce behaviors that lead to premarital sex. In addition to increasing premarital sexual moral judgments against the university can collaborate with relevant institutions BKKBN for example, by making the campus educational programs about the dangers of premarital sexual deviant behavior

Keywords - Attitudes about premarital sexual, Pre-conventional level of moral judgment, Conventional and post-conventional

\section{PENDAHULUAN}

Latar Belakang

Derguruan Tinggi merupakan salah satu jenjang pendidikan yang dapat ditempuh siswa setelah ia menyelesaikan pendidikan di Sekolah Menengah Atas. Saat Sekolah Menengah Atas mereka dikenal dengan sebutan siswa, ketika di Perguruan Tinggi, sebutan siswa menjadi mahasiswa, artinya siswa yang belajar di jenjang Perguruan Tinggi.

Sebagai mahasiswa bagaimana mereka menghadapi situasi yang ada dewasa ini menjadi suatu tantangan tersendiri karena mereka masih dalam usia yang tergolong remaja. Para ahli psikologi perkembangan menggolongkan remaja saat berusia 18 sampai dengan 24 tahun. Masa remaja merupakan suatu masa perkembangan individu yang diawali dengan matangnya organ-organ seksual dan telah mampu bereproduksi dan dikenal dengan masa pubertas. Masa perubahan fisik akibat pubertas mengarah pada ketertarikan yang kuat pada seksualitas. Pertumbuhan fisik remaja perempuan lebih awal dibandingkan remaja laki-laki. Tanda utama dari kematangan seksual pada perempuan adalah haid (menarche), dan tanda utama bagi naka laki- laki adalah ejakulasi pertama (spermache) atau yang baisa disebut "mimpi basah pertama kali". Besarnya ketertarikan para remaja terhadap seks bukanlah hal yang mengagetkan lagi. Pada tahap fisik/ragawi, mereka akan mengalami gairah terhadap seks yang disebabkan oleh perubahan hormon. Tidak hanya itu, mereka juga sudah mulai menyadari bahwa suatu saat mereka juga akan menjadi orang tua. Meningkatnya kemampuan kognitif mereka yang didapat melalui pengalaman-pengalaman mempunyai peran penting dalam cara mereka berpikir yang mungkin didominasi dengan perhatian-perhatiannya akan kesadaran terhadap diri sendiri, perkiraan-perkiraan mengenai diterima atau tidaknya di lingkungan sekitarnya, pemikiran yang berdasarkan hipotesis dan pembuatan keputusan perihal seks, berkencan/berpacaran, perilaku dan hubungan seksual.

Remaja putri biasanya mencemaskan perihal petting dan apa saja yang termasuk dalam seks, keperawanan, rasa sakit pada saat bersetubuh, dan kehamilan. Anak lakilaki justru lebih merasa penasaran pada kegiatan seksual itu sendiri seperti stimulasi yang dapat memberikan 
rangsangan dan reaksi seksual. Dapat dilihat sikap antara remaja putra dan putri sangat berbeda, cenderung remaja putri lebih negatif menyikapi seputar seks, sedangkan remaja putra lebih positif dalam menyikapinya

Berbagai faktor yang mempengaruhi remaja melakukan seks pranikah, diantaranya karena kematangan fisik, rasa ingin tahu yang tinggi mengenai masalah seks, meningkatnya penyebaran informasi dan rangsangan seksual melalui media massa. Informasi serta rangsangan yang menunjukkan aktivitas seksual terdapat pada sejumlah perantara media massa seperti koran dan majalah, pada media massa elektronik seperti situs porno internet, handphone, televisi, DVD/VCD porno. Jika berbicara mengenai perilaku seksual pranikah maka hal ini tidak terlepas dengan mereka yang berpacaran/berkencan. Aktivitas yang dilakukan mahasiswa saat berpacaran tidak hanya mengobrol, memeluk, atau mencium bibir tapi sudah lebih jauh yaitu melakukan petting (meraba payudara dan alat kelamin), dan sexual intercourse (hubungan kelamin, oral seks). Mereka berjalan dengan bergandengan tangan, merangkul bahkan terkadang terlihat tidak segan-segan untuk mencium pasangannya di depan umum. Hal ini menunjukan betapa mudahnya melakukan hubungan seks pranikah dikalangan remaja khususnya mahasiswa. Tetapi bagaimana dengan perkembangan moral mereka? Penalaran moral mereka apakah juga berperan jika dihubungkan dengan seksual pranikah?, karena seksual pranikah bukanlah suatu tindakan yang dapat dibenarkan baik oleh masyarakat maupun norma yang berlaku. Menurut Kolberg (dalam Papalia, 2009) cara individu melihat isu moral mencerminkan perkembangan kognitif mereka. Proses berpikir individu yang ditunjukkan dengan respon yang diproleh dari dilemma menggambarkan tiga tingkatan penalaran moral yaitu (1). Precoventional morality (usia 4-10 tahun) adalah individu berperilaku di bawah kontrol eksternal. Mereka menuruti peraturan untuk menghindari hukuman atau mendapatkan hadiah atau berperilaku karena mementingkan diri sendiri.(2) Conventional morality (setelah usia 10 tahun) : individu telah menginternalisasaikan standar dari figur otoritas . Mereka peduli tentang menjadi "baik", menyenangkan orang lain dan mempertahankan aturan sosial. Tingkat ini biasanya tercapai setelah usia 10 tahun, banyak orang tidak pernah bergerak naik dari tingkatan ini bahkan di masa dewasa. (3). Post vonventional morality: orang mengenal konflik antara standar moral dan membuat penilaian mereka sendiri berdasarkan prinsip kebenaran, keadilan dan hukum. Individu biasanya tidak mencapai tingkatan dari penalaran moral ini sampai setidaknya awal masa remaja atau lebih umum di masa dewasa awal, walaupun tidak semua orang mencapai tahap ini. Hasil penelitian Kolberg terhadap anak laki-laki di Amerika semua melalui tahapan tingkat perkembangan moral tersebut. Namun hasil penelitian terkini menunjukkan penilaian anak tentang hukum dan pelanggaran hukum membuktikan bahwa anak dapat berpikir secara fleksibel mengenai isu yang terjadi lebih dini dari usia yang ditetapkan oleh Kolberg (Papalia, 2009). Ketika mahasiswa dihadapkan pada situasi tentang isu seksual, pertanyaannya bagaimana sikap mereka dan bagaimana pula penilaian moral mereka terhadap isu tersebut. Hal ini penting untuk diketahui sebagai usaha preventif pencegahan berbagai kerugian yang dapat ditimbulkan dari munculnya penyakit melalui seksual pranikah. Di dalam kenyataannya ada mahasiswa sebagai remaja yang berpacaran, tetapi ada lagi yang belum pernah berpacaran atau sudah putus berpacaran. Melalui fenomena ini bagaimana mahasiswa sebagai remaja putra dan putri dalam menyikapi seks pranikah? Bagaimana pemikiran mereka? Apa yang mereka rasakan dan apa kecenderungan mereka terhadap seks pranikah? Apakah ada hubungan antara 
sikap terhadap seksual pranikah dengan tingkat perkembangan moral mereka? Nampaknya pertanyaan ini hanya dapat dijawab melalui suatu penelitian. Sebagai mahasiswa mereka masih dalam tahap perkembangan remaja dengan karakteristik perilaku menuju masa dewasa. Apakah ada hubungan antara sikap terhadap seksual pranikah dengan tingkat perkembangan moral pada mahasiswa?

\section{Identifikasi Masalah}

Kebudayaan yang semakin modern, dengan sendirinya menuntun masyarakat untuk mengambil bagian di dalamnya. Sikap yang semakin terbuka dalam menerima segala informasi yang ada, menyebabkan masyarakat cenderung mengikuti arus informasi tersebut. Hal ini juga terjadi pada sikap individu terhadap seksual pranikah, yang melibatkan perbedaan jenis kelamin di dalamnya, yaitu pria dan wanita. Seksual pranikah adalah segala tingkah laku yang didorong oleh hasrat seksual. Bentuk-bentuk tingkah laku seks pranikah dapat beraneka ragam, mulai dari perasaan tertarik hingga tingkah laku masturbasi, onani, berpegangan tangan, cium pipi, berpelukan, cium bibir, petting dan berhubungan seksual. Objek seksual dapat berupa orang, baik sejenis maupun lawan jenis, orang dalam khayalan atau diri sendiri.

Schulz dkk. (Dalam Azwar, 2005) menjelaskan faktor-faktor di luar individu dan di dalam individu mempengaruhi terjadinya seksual pranikah. Faktor di dalam individu yang cukup menonjol adalah sikap. Sikap atau attitude pertama kali digunakan oleh Herbert Spencer di tahun 1962 yang berarti status mental seseorang. Sikap dalam penelitian ini dibagi atas tiga komponen yang saling menunjang yaitu: komponen kognisi merupakan representasi apa yang di percayai oleh individu pemilik sikap, komponen afeksi merupakan perasaan yang menyangkut aspek emosional, dan komponen konasi merupakan aspek kecenderungan berperilaku tertentu sesuai dengan sikap yang dimiliki oleh seseorang (Azwar, 2005). Sikap itu sendiri banyak dipengaruhi oleh faktor luar dan dalam diri individu. Dengan demikian faktor sikap dapat dijadikan prediktor yang kuat terhadap munculnya seksual pranikah. Tetapi perlu diketahui juga bagaimana tentang tingkat perkembangan moralnya, mengingat seksual pranikah adalah tindakan yang tidak sesuai dengan norma sosial, norma agama dan aturan yang berlaku. Mahasiswa sebagai generasi muda dan penerus kehidupan berbangsa, perlu dicegah perilaku yang dapat merugikan kehidupannya di waktu yang akan datang.

\section{Perumusan Masalah}

Berdasarkan uraian pada latar belakang penelitian, maka dirumuskan masalah penelitian sebagai berikut:

1. Apakah ada hubungan antara sikap terhadap seksual pranikah dengan tingkat penilaian moral mahasiswa ?

2. Apakah ada hubungan sikap terhadap seksual pranikah dengan tahap perkembangan moral?

\section{Tujuan Penelitian}

Penelitian ini bertujuan untuk memberikan gambaran tentang hubungan sikap terhadap seksual pranikah dengan Tingkat penilaian moral pada mahasiswa Universitas Al Azhar Indonesia

\section{Ruang Lingkup}

Penelitian ini akan dilakukan dalam bentuk survey dengan mengkaji konsep teori yang di uji dalam kehidupan nyata melalui pengambilan data di lapangan. Oleh karena itu penelitian ini dilakukan secara crosssectional, dalam waktu yang sama dilakukan pengambilan data pada subjek penelitian yang beragam. Penelitian ini menggunakan dua variabel yaitu variabel sikap terhadap seksual pranikah dan penilaian moral dengan subjek penelitiannya adalah mahasiswa.

\section{Kontribusi Penelitian}

Penelitian yang akan dilakukan diharapkan dapat memberikan informasi pada :

1. Biro kemahasiswaan

Dari informasi yang diperoleh melalui penelitian ini dapat dijadikan bahan rujukan untuk mengambil langkah-langkah yang tepat untuk membekali mahasiswa tentang sikap dan penilaian moral terhadap seksual pranikah.

2. Dekan dan Kaprodi yang ada di lingkungan Universitas Al Azhar Indonesia Informasi tentang sikap dan penilaian moral terhadap seksual pranikah dapat dijadikan bahan pertimbangan untuk 
meningkatkan pencegahan perilaku sikap terhadap seksual pranikah pada mahasiswa

\section{TINJAUAN TEORI}

\section{Definisi Sikap}

Sikap atau attitude pertama kali digunakan oleh Herbert Spencer di tahun 1962 yang berarti status mental seseorang (Azwar, 2005).

a. Definisi pertama suatu sikap adalah bagaimana menerjemahkannya dalam hal positif atau hal negatif, kurang baik atau baik, atau ahli memperdayakan/menghafalkan seseorang ke arah suatu objek. Definisi ini memandang sikap sebagai perasaan atau suatu reaksi evaluatif ke objek.

b. Definisi kedua menghadirkan pemikiran Allport, yang memandang sikap sebagai kecendrungan bereaksi terhadap suatu objek atau kelas objek yang kurang baik atau baik. Definisi ini sedikit lebih rumit dibanding yang pertama sebab menyertakan dugaan suatu kesiap-siagaan untuk menjawab ke arah suatu objek.

c. Definisi ketiga adalah yang menjadi pandangan sikap sebagai hal yang menyusun dari tiga komponen: (1) kognisi (2) afeksi, dan (3) konasi.

\section{Komponen Sikap}

Struktur sikap terdiri atas tiga komponen yang saling menunjang yaitu: komponen kognisi merupakan representasi apa yang di percayai oleh individu pemilik sikap, komponen afeksi merupakan perasaan yang menyangkut aspek emosional, dan komponen konasi merupakan aspek kecenderungan berperilaku tertentu sesuai dengan sikap yang dimiliki oleh seseorang (Azwar, 2005):

1. Komponen kognisi

Komponen ini berkaitan dengan pengetahuan, pandangan, dan keyakinan tentang objek. Hal tersebut berkaitan dengan bagaimana orang mempersepsi objek sikap.

2. Komponen afeksi

Komponen afeksi terdiri dari seluruh perasaan atau emosi seseorang terhadap sikap. Perasaan tersebut dapat berupa rasa senang atau tidak senang terhadap objek, komponen ini menunjukkan ke arah sikap yaitu positif dan negatif. Komponen afeksi menyangkut masalah emosional subjektif seseorang terhadap suatu objek sikap, secara umum komponen afektif disamakan dengan perasaan yang dimiliki terhadap sesuatu. Namun pengertian perasaan pribadi seringkali sangat berbeda perwujudannya bila dikaitkan dengan sikap.

3. Komponen konasi

Komponen ini merupakan kecenderungan seseorang untuk bereaksi, bertindak terhadap objek sikap. Komponen ini menunjukkan intensitas sikap, yaitu besar kecilnya kecenderungan bertindak atau berperilaku seseorang terhadap objek sikap.

\section{Definisi Penilaian Moral}

Penilaian moral (moral judgement) menurut Kolberg (Dalam Papalia dkk.2009) merupakan proses berpikir yang dilakukan individu ketika dihadapkan pada isu dilemma moral. Kohlberg menekankan bahwa penentu kematangan moral adalah cara individu bernalar, bukan kandungan respons. Kolberg (1969) menggambarkan ada tingkatan dari perkembangan Moral yang masing-masing dibagi ke dalam dua tahap, yaitu :

\section{Tingkat: Prakonvensional}

Pada tahap ini moralitas dikendalikan dari luar. Mereka mematuhi aturan untuk menghindari hukuman atau mendapatkan hadiah, atau mereka bertindak karena kepentingan sendiri.

Tahap 1. Orientasi Hukuman dan Kepatuhan. Konsekuensi fisik menentukan apa yang dianggap baik atau buruk. Anak pada tahap ini sulit mempertimbangkan dua sudut pandang dalam sebuah dilemma moral. Akibatnya mereka mengabaikan niat orang dan fokus pada rasa takut pada otoritas dan menghindari hukuman sebagai alasan perilaku moral mereka.

\section{Tahap 2. Orientasi Relativisme}

Instrumental apapun yang memenuhi kebutuhan pribadi dianggap sebagai hal yang baik. Anak menyesuaikan dengan aturan untuk kepentingan dirinya sendiri dan mempertimbangkan apa yang orang lain dapat lakukan untuk mereka. Mereka lebih melihat tindakan sebagai bentuk pemenuhan kebutuhan manusia dan membedakan nilai ini dari bentuk tindakan fisik dan konsekuensinya. 


\section{Level 2: Konvensional}

Pada tahap ini individu tetap menganggap bahwa kesesuaian dengan aturan sosial itu penting, tetapi bukan karena alasan kepentingan diri. Mereka yakin bahwa aktif memelihara sistem sosial saat ini dapat menjamin hubungan positif dan keteraturan sosial.

\section{Tahap 3. Orientasi Indeks Interpersonal}

Apapun yang menyenangkan atau membantu orang lain dianggap sebagai hal yang baik. Individu pada tahap 3 ini ingin memelihara kasih sayang dan persetujuan dari teman dan kerabat dengan menjadi orang baik, jujur, setia, hormat, penolong, dan menyenangkan. Mereka mengevaluasi tindakan berdasarkan motif di belakangnya atau apa yang ditampilkan individu tersebut, dan mereka memperhitungkan situasi.

Tahap 4. Orientasi "Hukum" dan "Aturan" Tahap ini mempertahankan keteraturan sosial dan melaksanakan kewajiban dianggap sebagai hal yang baik. Pada tahap ini individu memperhitungkan yang lebih luas, perspektif hukum masyarakat. Pilihan moral tidak lagi bergantung pada hubungan dekat dengan orang lain. Sebaliknya, peraturan harus ditegakkan dalam cara yang adil untuk semua orang, dan setiap anggota masyarakat memiliki tugas pribadi untuk menegakkan peraturan itu. Individu pada Tahap 4 ini percaya bahwa hukum tidak boleh dilanggar karena sifatnya yang penting dalam menjamin ketertiban masyarakat dan hubungan kerja sama antara individu.

\section{Level 3: Pasca konvensional}

Pada tahap ini individu mengenali konflik antara standar moral dan membuat penilaian mereka sendiri yang berdasarkan prinsip kebenaran, kejujuran, dan keadilan. Mereka mendefinisikan moralitas menurut prinsipprinsip abstrak dan nilai-nilai yang berlaku bagi semua situasi dan masyarakat.

Tahap 5. Orientasi kontrak sosial- legalistik Nilai-nilai yang disepakati oleh masyarakat menentukan hal-hal yang dianggap baik. Individu berpikir dalam konteks rasional, menilai hal keinginan dari mayoritas dan kesejahteraan kelompok sosial. Mereka umumnya melihat nilai tersebut sebagai dukungan terbaik untuk menyelaraskan hukum.
Sementara mereka mengenali bahwa ada saatnya kebutuhan manusia dan hukum berkonflik, mereka percaya bahwa baik bagi kelompok sosial dalam jangka panjang jika mereka patuh pada hukum.

Tahap 6. Orientasi Prinsip - Prinsip Etik yang Sifatnya Universal

apa yang dianggap benar merupakan bagian suara hati yang diperoleh dari prinsip-prinsip universal. Pada tahap ini adalah tahap tertinggi, dimana tindakan benar didefinisikan oleh prinsip-prinsip etika kesadaran yang berlaku untuk semua orang, terlepas dari hukum dan kesepakatan sosial. Individu pada Tahap 6 ini biasanya menyebutkan prinsip-prinsip seperti menghargai nilai dan martabat setiap orang.

Teori Kolberg tentang tahap perkembangan moral diukur dengan alat ukur yang ia ciptakan. Namun cara skoringnya dianggap oleh pengguna alat ukur tersebut sulit dilakukan. Oleh karena itu James Rest (1986) menciptakan alat ukur terkait dengan moral judgement yang mudah untuk digunakan dan diskoring. Alat pengukuran tentang penilaian moral ini sebagai alat alternatif untuk mengatasi kesulitan penggunaan dan skoring dari implementasi konsep tahapan perkembangan moral Kolberg. Skor yang paling banyak digunakan adalah skor $\mathrm{P}$ yang merupakan presentasi dari pemikiran prinsip (principled thingking).

Kedua teori baik dari Kolberg dan Rest, merupakan teori yang dapat menggambarkan tahapan perkembangan moral dari individu. Sejauh mana tahapan atau tingkatan perkembangan moral dapat dikatehui dari jawaban terhadap alat ukur yang berisi issue dilemma moral.

\section{Remaja \\ Definisi Remaja}

Dibawah ini terdapat tiga definisi yang berkaitan dengan remaja:

"Adolescence is developmental transition between childhood and adulthood entailing major physical, cognitive, and psychososial changes" (Papalia, Olds \& Feldman, 2009)

"Adolescence as the period of transition between childhood and adulthood, consisting of biological, physical, cognitive, and social emotion, personal changes" (Santrock, 2003) Kesimpulan yang dapat ditarik dari kedua definisi mengenai remaja di atas adalah 
seseorang dapat disebut sebagai remaja ketika dia mulai memasuki periode transisi antara masa kanak-kanak dan masa dewasa. Perubahan yang dialami meliputi perubahan fisik, kognitif, dan psikososial. Beberapa ahli membagi masa remaja menjadi dua bagian yaitu early adolescence dan late adolescence. Early adolescence adalah remaja yang berusia 11-19 tahun dan yang sedang mengalami masa pubertas, sedangkan late adolescence adalah remaja yang hampir atau sudah memasuki usia 20 tahun (Santrock, 2003). Pada penelitian ini yang menjadi subyek penelitian adalah late adolescence atau remaja akhir. Pada penelitian ini yang menjadi subjek penelitian adalah late adolescence atau remaja akhir.

Remaja yang akan menjadi subjek dalam penelitian ini adalah remaja akhir. Kesimpulan yang dapat ditarik dari berbagai literatur (Papalia et al. 2009 dan Santrock, 2001) remaja akhir memiliki ciri-ciri sebagai berikut:

1. Stabilitas mulai timbul dan meningkat Pada tahap ini remaja mulai menunjukan adanya kestabilan dalam aspek-aspek fisik dan psikis.

2. Citra diri dan pandangan lebih realistis Pada masa sebelumnya yaitu masa remaja awal, remaja sangat sering memandang dirinya lebih tinggi atau lebih rendah dari keadaan sesungguhnya. Tetapi pada masa remaja akhir keadaan semacam itu telah berkurang. Pada masa ini remaja telah mulai menilai dirinya sebagaimana adanya, menghargai miliknya, keluarganya, orang lain seperti yang sesungguhnya.

3. Menghadapi masalah secara lebih matang Pada masa ini remaja mulai dapat menghadapi masalah lebih matang yang ditunjukan dengan usaha pemecahan masalah yang dihadapi.

4. Perasaan menjadi lebih tenang

Dalam menghadapi masalah masa remaja akhir lebih tenang. Kalau pada masa awal mereka memperlihatkan kemarahan, kesedihan dalam menghadapi masalah. Hal ini tidak terjadi pada masa remaja akhir, pada masa remaja mulai dapat mengendalikan emosi.

5. Perkembangan kognitif

Menurut Piaget, pada masa ini remaja sudah memasuki tahap formal operational. Formal operational adalah tahapan akhir dari perkembangan kognitif, yang ditandai dengan kemampuan untuk memanipulasi informasi, tidak hanya here and now. Tetapi tidak semua remaja mampu mengembangkan kemampuannya untuk berpikir formal operational secara penuh, karena itu beberapa ahli perkembangan meyakini bahwa tahap berpikir formal operational terbagi dalam dua sub periode yaitu: early formal operational dan late formal operational. Early formal operational adalah kemampuan remaja untuk meningkatkan kemampuan berpikir secara hipotesis, melahirkan dugaandugaan dengan kemungkinan yang tidak terbatas sehingga terkadang berlebihlebihan yang pada akhirnya memberi kesan bahwa mereka sangat subjektif dan idealis. Tahapan ini berlangsung pada usia early adolescence. Sedangkan tahapan late formal operational memperbaiki keseimbangan intelektual remaja dengan berpikir secara nalar dan digabungkan dengan pengalaman. Tahapan ini berlangsung pada usia late adolescence.

6. Pentingnya hubungan dengan kelompok teman sebaya

Pada remaja mulai timbul keinginan untuk membentuk hubungan yang lebih intim dengan teman sebaya (peers) baik dengan teman sejenis ataupun lawan jenis.

\section{Perilaku Seksual Pranikah}

Perilaku seks pranikah adalah segala tingkah laku yang didorong oleh hasrat seksual, baik dengan lawan jenis maupun sesama jenis sebelum pernikahan (Sarwono, \& Meinaro, 2014). Sikap terhadap perilaku seks pranikah adalah perasaan mendukung atau memihak (favourable) maupun perasaan tidak mendukung/tidak memihak (unfavourable) pada segala tingkah laku yang didorong oleh hasrat seksual, baik dengan lawan jenis maupun sesama jenis sebelum terikat tali perkawinan yang syah.

Bentuk-bentuk tingkah laku seks pranikah dapat beraneka ragam, mulai dari perasaan tertarik hingga tingkah laku masturbasi, onani, berpegangan tangan, cium pipi, berpelukan, cium bibir, petting dan berhubungan seksual. Objek seksual dapat berupa orang, baik sejenis maupun lawan jenis, orang dalam khayalan atau diri sendiri. 
Papalia \& Olds (2009) mengungkapkan beberapa gradasi aktivitas seksual yang dilakukan oleh remaja yaitu: berciuman, membelai atau mencium sekitar leher, merabaraba payudara atau alat kelamin, hingga melakukan hubungan kelamin.Hubungan antar jenis mengandung banyak variasi, ada suatu peningkatan kedekatan fisik yang sangat jelas, keintiman heteroseksual bertingkat melalui tahap-tahap sebagai berikut: Touching (Memegang atau memeluk pasangan.). 2. Kissing (Berkisar mulai dari ciuman yang singkat dan cepat kepada ciuman yang lama dan lebih intim (deep kissing). 3. Petting (Menyentuh atau meraba-raba daerah erotis dari pasangan yang biasanya dari meraba-raba alat kelamin). Sexual intercourse (Hubungan kelamin atau senggama).

\section{Hipotesis Penelitian}

Ada hubungan antara Sikap Terhadap Seksual Pranikah Dengan Tingkat Penilaian Moral pada Mahasiswa.

\section{METODOLOGI PENELITIAN}

\section{Rancangan Penelitian}

Rancangan penelitian yang akan digunakan adalah penelitian korelasional yaitu untuk mengetahui hubungan antara satu variabel dengan variabel lainnya dengan cara mengukur setiap variabel kemudian dilihat korelasinya atau sejauhmana keterkaitan antar variabel dengan bantuan metode statistik.

\section{Variabel Penelitian}

Variabel yang berperan dalam penelitian ini adalah:

1. Sikap terhadap seksual pranikah (X)

2. Tingkat Penilaian moral (Y)

\section{Definisi Operasional Variabel}

Sikap terhadap Seksual pranikah adalah:

Kecenderungan berperilaku seksual pranikah berdasarkan unsur kognitif, afektif dan konatif /psikomotor

Penilaian moral (moral judgement) adalah: Proses berpikir yang dilakukan individu ketika dihadapkan pada issue dilemma moral.

\section{Populasi dan Subjek Penelitian}

Populasi dalam penelitian ini adalah mahasiswa Universitas Al Azhar Indonesia Subjek penelitiannya ditetapkan dengan menggunakan teknik accidental random sampling. Teknik sampling ini adalah suatu cara pengambilan sampel dimana subyek dalam suatu populasi diambil secara random pada mahasiswa yang ada di populasi.

\section{Instrumen Pengambilan Data:}

1. Alat Ukur Sikap terhadap seksual

2. Pranikah Alat Ukur Penilaian Moral

Alat pengumpulan data yang dipergunakan dalam penelitian ini adalah kuesioner, dalam bentuk skala. Alat ukur ini merupakan salah satu jenis alat pengumpulan data yang disampaikan kepada responden atau subyek penelitian melalui sejumlah daftar pernyataan tertulis yang berhubungan dengan variabel penelitian. Metode ini merupakan self-report yang digunakan karena kemudahan pelaksanaan, dimana subjek dapat mempertahankan anonimitasnya.

Alat ukur dalam penelitian ini terdiri dari pernyataan kuesioner isian dan tertutup (fixed alternative question), dengan bentuk skala Likert . Pernyataan-pernyataan dalam skala terdiri dari pernyataan yang menyenangkan (favourable) dan tidak menyenangkan (unfavorable) . Alat tersebut disusun berdasarkan teori yang dipergunakan dalam penelitian ini.

Berdasarkan Arikunto (2002) dalam pengembangan skala Likert, peneliti boleh saja memperkecil atau memperluas penskalaan menjadi tiga, empat, lima, enam atau lebih banyak lagi. Pemilihan alternative diserahkan pada keinginan dan kepentingan peneliti yang menciptakan instrument tersebut.

\section{Uji Reliabilitas}

Reliabilitas adalah indeks yang menunjukkan sejauh mana suatu alat ukur dapat dipercaya atau diandalkan. Apabila suatu alat ukur dapat dipakai dua kali untuk mengukur dua gejala yang sama dan hasil penelitian relative konsisten, maka alat ukur tersebtu dikatakan reliable. Reliabilitas menunjuk kepada taraf keterpercayaan atau taraf konsistensi hasil ukur (Azwar, 2005)

Untuk mengukur reliabilitas yang dihasilkan digunakan teknik Alpha Cronbach, dengan langkah-langkah sebagai berikut: 
a. Membagi item-item yang mempunyai daya beda ke dalam dua belahan berdasarkan kelompok ganjil dan genap

b. Menghitung skor item pada belahan 1 dan 2 berikut skor total item

c. Menghitung varians dari belahan 1, belahan 2 dan total

d. Mencari angka validitas keseluruhan item dengan menggunakan rumus sebagai berikut:

$$
\mathrm{rxx}=\alpha=2\left(1-\frac{\mathrm{S} 1^{2}+\mathrm{S} 2^{2}}{\mathrm{~S}^{2} \mathrm{X}}\right)
$$

Keterangan :

$\mathrm{rxx}=$ Koefisien Korelasi

$\alpha=$ Koefisien reliabilitas alpha

$\mathrm{S}^{2}=$ Varians skor belahan 1

$\mathrm{S}^{2}=$ Varians skor belahan 2

$\mathrm{S}^{2} \mathrm{X}=$ varians skor total

Parameter untuk menafsirkan tinggi rendahnya koefisien reliabilitas alat ukur dan ada tidaknya korelasi antara dua variable atau lebih, menurut Guilford adalah sebagai berikut:

Kurang dari 0.20 : tidak ada korelasi

$0.20-0.40 \quad: \quad$ korelasi rendah

$0.40-0.70 \quad: \quad$ korelasi tinggi

$0.70-0.90 \quad: \quad$ korelasi tinggi sekali

$1.0 \quad:$ korelasi sempurna

\section{Uji Validitas Alat Ukur}

Validitas alat ukur adalah tingkat sesuatu alat ukur yang mampu mengukur apa yang hendak diukur (Arikunto,2002). Validitas alat ukur dilakukan dengan cara tryout terpakai, dalam arti subjek yang digunakan untuk mencari validitas item akan digunakan sebagai subjek penelitian

\section{Analisis Data}

Dalam penelitian ini akan dipergunakan berbagai uji statistik, baik dalam menganalisis uji coba alat pengumpulan data, metode analisis hasil data utama. Uji statistik akan menggunakan perangkat lunak komputer SPSS 20.0 (Yamin \& Kurniawan, 2009)

Sebelum kuesioner digunakan sebagai alat pengumpul data dalam penelitian sesungguhnya, maka dilakukan pengujian validitas dan reliabilitas item. Pengujian validitas bertujuan untuk mengetahui nilai diskriminasi item, yaitu berapa besar nilai antar individu yang memiliki skor tinggi dan skor rendah pada suatu kriteria. Pengujian ini menggunakan teknik inter item consisteny, yaitu dengan menghitung korelasi skor item dengan skor total item. Teknik statistik yang digunakan adalah formula korelasi Pearson's Product Moment. Sedangkan pengujian reliabilitas kuesioner dilihat untuk melakukan seberapa jauh alat memberikan hasil yang relatif tidak berbeda bila dilakukan pengukuran kembali terhadap gejala yang sama. Perhitungan koefisien reliabilitas dilakukan dengan menggunakan teknik statistik Alpha Cronbach. Metode analis hasil data utama dalam rangka menjawab masalah operasional dari penelitian, dipergunakan uji korelasi Pearson's Product Moment. Selain itu juga ditambahkan analisa data secara deskriptif, yaitu mean, median, dan modus.

\section{HASIL DAN PEMBAHASAN}

\section{Hasil Analisis Data Deskriptif}

Pengolahan data penelitian ini diawali dengan statistika deskriptif, yang merupakan metoda untuk memberikan gambaran menyeluruh tentang suatu atau beberapa kelompok dengan cara menyusun dan merangkum data kelompok/sampel.

Adapun hasil pengolahan data terkait rata-rata aspek sikap adalah sebagai berikut:

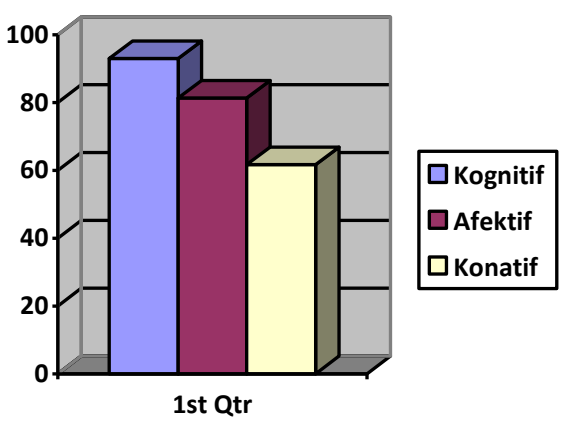

Gambar 1. Hasil Pengolahan Data Terkait Rata Rata Aspek Sikap

Berdasarkan grafik diatas terlihat bahwa aspek sikap terhadap seksual pranikah yang paling tinggi tercermin dalam komponen kognisi, yang merupakan representasi dari apa yang di percayai oleh mahasiswa terkait pengetahuan, pandangan, dan keyakinan tentang seksual pranikah. Hal tersebut menggambarkan bahwa bagaimana mahasiswa mempersepsikan 
perilaku seksual pranikah lebih dominan dibandingkan komponen afeksi yang terkait perasaan dan emosi serta komponen konasi yang terkait kecenderungan dalam bereaksi terhadap perilaku seksual pranikah.

Berikutnya juga diperoleh data rata-rata aspek tahapan moral sebagai berikut:

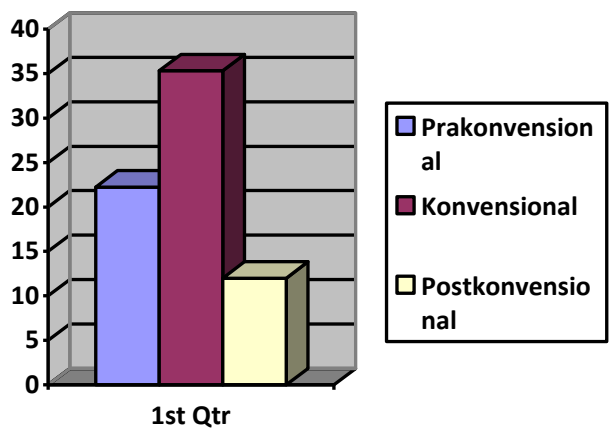

Gambar 2. Data Rata - Rata Aspek Tahapan Moral

Grafik diatas menggambarkan bahwa level konvensional adalah level yang paling dominan pada penalaran moral mahasiswa UAI. Dimana, pada tahap ini mahasiswa tetap menganggap bahwa kesesuaian dengan aturan sosial itu penting, tetapi bukan karena alasan kepentingan diri. Mereka yakin bahwa aktif memelihara sistem sosial saat ini dapat menjamin hubungan positif dan keteraturan sosial.

Tabel 1 merupakan hasil analisis deskriptif masing-masing variabel:

Tabel 1. Hasil Analisis Deskreptif Masing - Masing Variabel

\begin{tabular}{|c|c|c|c|c|}
\hline \multicolumn{5}{|c|}{$\begin{array}{r}\text { Descriptives } \\
\end{array}$} \\
\hline & & & $\begin{array}{c}\text { Statisti } \\
\mathrm{c}\end{array}$ & $\begin{array}{l}\text { Std. } \\
\text { Error }\end{array}$ \\
\hline \multirow{7}{*}{$\begin{array}{l}\text { VA } \\
\text { R0 } \\
000 \\
1\end{array}$} & \multicolumn{2}{|l|}{ Mean } & 2.45 & $\begin{array}{l}0.03 \\
238\end{array}$ \\
\hline & \multirow{2}{*}{$\begin{array}{c}95 \% \\
\text { Confiden } \\
\text { e Interva } \\
\text { for Mean }\end{array}$} & $\begin{array}{l}\text { Lower } \\
\text { Bound }\end{array}$ & 2.3849 & \\
\hline & & $\begin{array}{l}\text { Upper } \\
\text { Bound }\end{array}$ & 2.5151 & \\
\hline & \multicolumn{2}{|c|}{ Trimmed } & 2.4531 & \\
\hline & \multicolumn{2}{|l|}{ Median } & 2.4444 & \\
\hline & \multicolumn{2}{|l|}{ Variance } & 0.052 & \\
\hline & \multicolumn{2}{|c|}{ Std. Deviation } & 0.2289 & \\
\hline
\end{tabular}

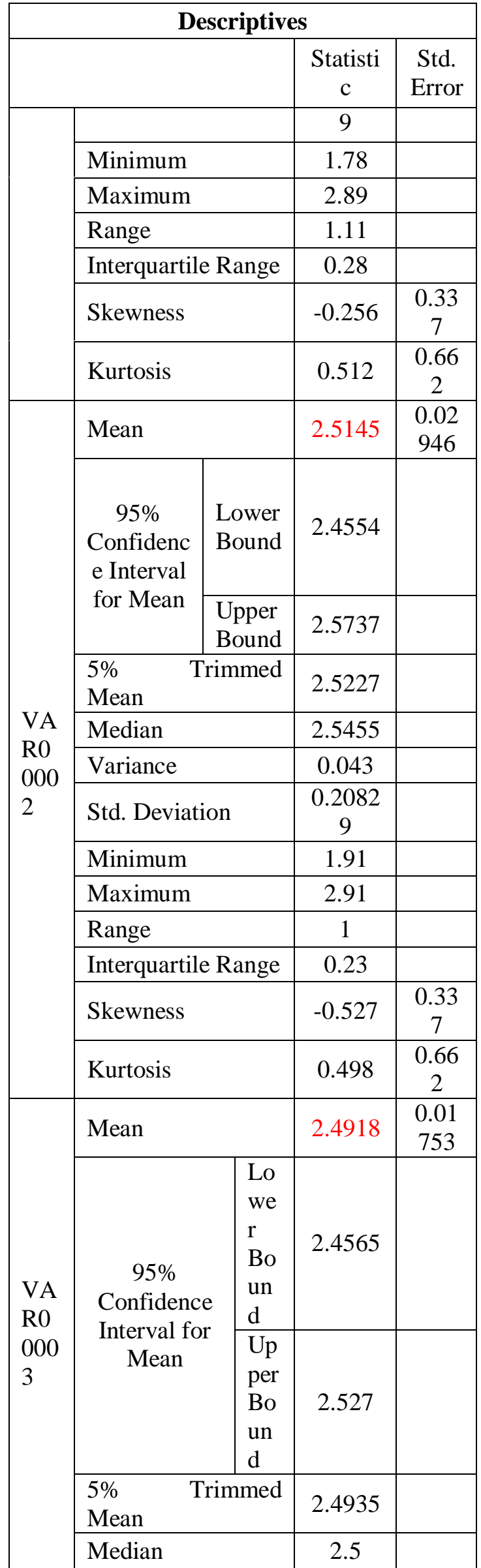




\begin{tabular}{|c|c|c|}
\hline \multicolumn{3}{|c|}{ Descriptives } \\
\hline & $\begin{array}{l}\text { Statisti } \\
\text { c }\end{array}$ & $\begin{array}{c}\text { Std. } \\
\text { Error }\end{array}$ \\
\hline Variance & 0.015 & \\
\hline Std. Deviation & $\begin{array}{c}0.1239 \\
4\end{array}$ & \\
\hline Minimum & 2.18 & \\
\hline Maximum & 2.76 & \\
\hline Range & 0.59 & \\
\hline Interquartile Range & 0.18 & \\
\hline Skewness & -0.171 & $\begin{array}{c}0.33 \\
7\end{array}$ \\
\hline Kurtosis & 0.059 & $\begin{array}{c}0.66 \\
2\end{array}$ \\
\hline
\end{tabular}

\section{Hasil Analisis Korelasi}

Tabel 2. Hasil Analisis Kolmogrof Smirnov

\begin{tabular}{|l|r|r|r|r|r|}
\hline & \multicolumn{2}{|c|}{ Kolmogorov-Smirnov } & \multicolumn{3}{|c|}{ Shapiro-Wilk } \\
\cline { 2 - 6 } & \multicolumn{1}{|c|}{ Statistic } & \multicolumn{1}{c|}{ Sig. } & Statistic & df & \multicolumn{1}{c|}{ Sig. } \\
\hline $\begin{array}{l}\text { VAR0 } \\
\text { O001 }\end{array}$ & 0.085 & $.200^{*}$ & 0.978 & 50 & 0.485 \\
\hline $\begin{array}{l}\text { VAR0 } \\
0002\end{array}$ & 0.119 & 0.074 & 0.966 & 50 & 0.163 \\
\hline $\begin{array}{l}\text { VAR0 } \\
0003\end{array}$ & 0.119 & 0.072 & 0.976 & 50 & 0.413 \\
\hline
\end{tabular}

\begin{tabular}{|l|l|r|}
\hline \multicolumn{3}{|c|}{ Correlations } \\
\hline \multirow{2}{*}{ Sikap } & Moral \\
\hline \multirow{5}{*}{ Moral } & $\begin{array}{l}\text { Pearson } \\
\text { Correlation }\end{array}$ & 0.072 \\
\cline { 2 - 3 } & Sig. (2-tailed) & 0.618 \\
\cline { 2 - 3 } & N \\
\hline \multirow{4}{*}{} & $\begin{array}{l}\text { Pearson } \\
\text { Correlation }\end{array}$ \\
\cline { 2 - 3 } & Sig. (2-tailed) & \\
\cline { 2 - 3 } & N & 50 \\
\hline
\end{tabular}

Untuk menjawab hipotesis penelitian, maka digunakan uji korelasi Pearson's Product Moment dengan hasil output SPSS sebagai berikut:

Dari output tersebut terlihat bahwa nilai Pearson Correlation $\mathrm{r}=0.072$, dengan nilai $\mathrm{p}$ value $(0,618>0,05)$, maka Ho diterima. Dapat disimpulkan bahwa hipotesis penelitian ditolak yang berarti bahwa sikap terhadap seksual pranikah (X) tidak memiliki korelasi secara signifikan dengan penilaian moral (Y) pada mahasiswa UAI.

Tabel 3. Hasil Analisis Hubungan Sikap Seksual Pra Nikah

\begin{tabular}{|c|c|c|c|c|}
\hline \multicolumn{5}{|c|}{ Correlations } \\
\hline & & pra & kon & post \\
\hline \multirow{3}{*}{ Sikap } & $\begin{array}{l}\text { Pearson } \\
\text { Correlation }\end{array}$ & 0.115 & 0.053 & -0.027 \\
\hline & Sig. (2-tailed) & 0.425 & 0.716 & 0.851 \\
\hline & $\mathrm{N}$ & 50 & 50 & 50 \\
\hline \multirow{3}{*}{ pra } & $\begin{array}{l}\text { Pearson } \\
\text { Correlation }\end{array}$ & 1 & $.546^{* *}$ & $.347^{*}$ \\
\hline & Sig. (2-tailed) & & 0 & 0.014 \\
\hline & $\mathrm{N}$ & 50 & 50 & 50 \\
\hline \multirow{3}{*}{ kon } & $\begin{array}{l}\text { Pearson } \\
\text { Correlation }\end{array}$ & $.546^{* *}$ & 1 & $.341^{*}$ \\
\hline & Sig. (2-tailed) & 0 & & 0.015 \\
\hline & $\mathrm{N}$ & 50 & 50 & 50 \\
\hline \multirow{3}{*}{ post } & $\begin{array}{l}\text { Pearson } \\
\text { Correlation }\end{array}$ & $.347^{*}$ & $.341^{*}$ & 1 \\
\hline & Sig. (2-tailed) & 0.014 & 0.015 & \\
\hline & $\mathrm{N}$ & 50 & 50 & 50 \\
\hline \multicolumn{5}{|c|}{$\begin{array}{l}\text { **. Correlation is significant at the } 0.01 \text { level ( } 2 \text { - } \\
\text { tailed). }\end{array}$} \\
\hline \multicolumn{5}{|c|}{$\begin{array}{l}\text { *. Correlation is significant at the } 0.05 \text { level (2- } \\
\text { tailed). }\end{array}$} \\
\hline
\end{tabular}

Output diatas juga menunjukkan bahwa tidak terdapat hubungan yang signifikan antara sikap terhadap seksual pranikah dengan ketiga level perkembangan moral pada mahasiswa UAI yang terdiri dari level pra konvensional, konvensional, dan post konvensional dengan nilai $\mathrm{p}$ value >0,05. Semakin tinggi sikap terhadap seksual pranikah, maka semakin tinggi pula perkembangan moral pra konvensional dan konsvensional pada mahasiswa. Namun, semakin tinggi sikap terhadap seksual pranikah maka semakin rendah level perkembangan moral post konvensional pada mahasiswa UAI.

\section{Pembahasan Penelitian}

Hasil tersebut menunjukkan bahwa kecenderungan untuk melakukan seksual pranikah yang terdiri dari aspek kognisi, afeksi dan konasi tidak memiliki korelasi dengan penilaian moral. Walaupun penilaian moral menghadapkan mahasiswa pada isu dilemma terkait seksual pranikah yang bertentangan 
dengan norma sosial maupun agama Islam, namun hal tersebut tidak berhubungan dengan sikap mereka terhadap perilaku seksual pranikah itu sendiri. Semakin tinggi kecenderungan melakukan seksual pranikah, maka semakin rendah penilaian moral pada level pasca konvensional mahasiswa tersebut. Mahasiswa pada masa remaja menganggap hubungan dengan kelompok teman sebaya sangat penting, timbul keinginan untuk membentuk hubungan yang lebih intim baik dengan teman sejenis ataupun lawan jenis. Untuk itu, diperlukan dukungan dari lingkungan agar remaja dapat mencapai level perkembangan moral maksimal yang menjunjung prinsip etika berdasarkan kesadaran diri pribadi. (Papalia et al. 2009 dan Santrock, 2001) Sehingga diharapkan mahasiswa bersikap tidak memihak/mendukung tingkah laku yang didorong oleh hasrat seksual, baik dengan lawan jenis maupun sesama jenis sebelum terikat tali perkawinan yang syah. Tingginya aspek kognitif dibandingkan dengan aspek afektif dan konatif berarti mahasiswa sebagai remaja adalah perlu membuat keseimbangan antara berpikir secara nalar dengan keinginannya untuk mencari pengalaman dalam berhubungan dengan lawan jenis, agar tidak terjebak dalam perasaan atau kecenderungan berperilaku terhadap seksual pranikah.

Dari data tentang tahap perkembangan moral, tahap prakonvensional lebih tinggi dari pada tahap pasca konvensional, dan tahap konvensional lebih tinggi dibandingkan dengan tahap pra konvensional maupun pasca konvensional. Data ini menunjukkan bahwa mahasiswa menganggap bahwa penilaian moral mereka lebih dikendalikan oleh aturan yang berlaku dan menghindari hukuman berdasarkan kepentingan yang mereka miliki. Mereka fokus pada rasa takut pada otoritas dan menghindari hukuman sebagai alasan dari perilaku moral mereka.dengan kata lain mereka menyesuaikan antara kepentingan diri sendiri dengan mempertimbangkan apa yang dapat orang lain dapat lakukan untuk mereka.

Di sisi lain data pada tahap pasca convensional tergolong paling rendah, mahasiswa menilai masalah moral merupakan masalah kesejahteraan kelompok sosial. Apa yang dianggap benar merupakan prinsip-prinsip yang berlaku secara universal. Tahapan ini merupakan tahapan yang bersifat abstrak yang berlaku bagi semua manusia. Mahasiswa belum banyak menilai bahwa masalah moral merupakan prinsip universal, mereka lebih menilai permasalahan moral sebagai sistem sosial yang berlaku disuatu tempat sesuai dengan aturan yang telah ditetapkan.

Data pada tahap konvensional lebih tinggi dari tahap yang lain, menunjukkan bahwa mahasiswa ingin menjadi orang yang baik, jujur setia, penolong dan menyenangkan. Mereka memperhitungkan motif dari setiap tindakan yang dilakukan dengan memperhatikan situasi yang ada. Penilaian moral tidak lagi bergantung pada hubungan dekat dengan orang lain, tetapi lebih pada pentingnya peraturan yang adil ditegakkan pada semua orang. Setiap anggota masyarakat memiliki tugas pribadi untuk menegakkannya. (Kolberg dalam Gerk, Laura E. 2012). Jika penilaian moralnya adalah sikap terhadap seksual pranikah, berarti mereka sebagai anggota masyarakat secara pribadi menganggap penting untuk menjalankan aturan moral yang telah ditetapkan. Mempertahankan dan melaksanakan keteraturan sosial dianggap sebagai hal yang baik. Ada perpektif hukum yang berperan dalam menilai seksual pranikah, baik secara hukum agama maupun hukum yang berlaku. Mereka juga memperhitungkan motif dibalik setiap tindakan terhadap seksual pranikah. Tingginya tahap perkembangan moral mahasiswa pada tahap konvensional, berarti masalah seksual pranikah tidak mereka lakukan secara serampangan, mereka memperhitungkan aturan agama, aturan hukum dan aturan sosial.

Perbedaan tahap penilaian moral pada mahasiswa sejalan dengan pendapat Kolberg, yang menyatakan bahwa adanya perbedaaan penilaian moral dengan perilaku karena ada faktor situasional, motivasional dan emosional.jika situasinya berbeda penilaian moral mereka juga berbeda. Berdasarkan observasi pada mahasiswa sebagain dari mereka sudah menjalin hubungan antar lawan jenis atau yang sering disebut dengan pacaran. Ada yang menunjukkan secara terang-terangan perilaku terhadap pacarnya didepan umum secara mesra, tetapi ada juga yang tidak menunjukkan secara terbuka perilaku yang mengarah pada kecenderungan terhadap seksual pranikah. Sesuai dengan tahap 
perkembangan mereka di remaja akhir mereka sudah tertarik terhadap lawan jenis. Jika data observasi dihubungkan dengan tahap perkembangan moral konvensional yang memperoleh data tertinggi, artinya mahasiswa masih tetap memperhatikan aturan agama, aturan hukum dan aturan sosial dalam menunjukkan sikap terhadap seksual pranikah.

\section{KESIMPULAN DAN SARAN}

\section{Kesimpulan}

Berdasarkan analisis statistik dengan menggunakan Pearson Correlation, diperoleh hasil:

1. Hubungan sikap terhadap seksual pranikah dengan tingkap penilaian moral sebesar r.072, berarti tidak terdapat hubungan yang signifikan antara sikap terhadap seksual pranikah dengan penilaian moral pada mahasiswa UAI.

2. Hubungan sikap terhadap seksual pranikah dengan tahap penilaian moral prakonvensional r.115 berarti tidak terdapat hubungan yang signifikan antara sikap terhadap seksual pranikah dengan penilaian moral prakonvensional pada mahasiswa UAI.

3. Hubungan sikap terhadap seksual pranikah dengan tahap penilaian moral konvensional r. 053 berarti tidak terdapat hubungan yang signifikan antara sikap terhadap seksual pranikah dengan penilaian moral konvensional pada mahasiswa UAI

4. Hubungan sikap terhadap seksual pranikah dengan tahap penilaian moral pasca konvensional r.-027 berarti tidak terdapat hubungan yang signifikan antara sikap terhadap seksual pranikah dengan penilaian moral pasca konvensional pada mahasiswa UAI

\section{Saran}

1. Tahap penilaian moral mahasiswa masih banyak pada tahap konvensional. Pada mahasiswa perlu lebih banyak diajak diskusi dan menalar untuk meningkatkan pengetahuan bagaimana bersikap terhadap seksual paranikah, agar mereka dapat menegakkan aturan agama, aturan hukum dan aturan sosial disaat mereka menjalin hubungan dengan lawan jenis.
2. Bagi universitas, bekerjasama dengan orang tua dapat membuat program pembinaan bersama baik dikampus maupun di rumah tentang sikap terhadap seksual pranikah. Pihak universitas maupun orang tua membuat program yang dapat menstimulasi penilaian moral mahasiswa dengan memberikan perhatian yang lebih tentang bagaimana seharusnya mahasiswa menilai sikap terhadap seksual pranikah. Aturan yang diterapkan dikampus, perlu diterapkan juga di saat mereka berada di rumah agar penilaian moral mereka terhadap sikap pada seksual pranikah menjadi lebih baik dan mengurangi perilaku yang mengarah pada seksual pranikah. Sikap mahasiswa terhadap seksual pranikah mencerminkan penilaian moral mereka sebagai remaja yang menuju dewasa.

3. Untuk meningkatkan penilaian moral terhadap seksual pranikah pihak universitas dapat bekerjasama dengan insitusi terkait misalnya BKKBN, dengan membuat program edukasi dikampus tentang bahaya perilaku seksual pranikah

\section{DAFTAR PUSTAKA}

[1] Azwar, Saifuddin. 2010. Penyusunan Skala Psikologi. Yogyakarta: Pustaka Pelajar.

[2] Arikunto, Suharsimi. 2002. Prosedur Penelitian Suatu Pendekatan Praktek. Edisi Revisi V. Jakarta: Rineka Cipta.

[3] Atkinson, R.L.Richard, E.E.S.Dary, I.J.B.M. 1996. Introduction to Psychology. New York: Harcout Beace College Publishing.

[4] Desmita. 2005. Psikologi Perkembangan. Bandung: PT Remaja Rosdakarya.

[5] Elmes, David G., Kantowitz, Barry H., Roediger III, Henry L. 2014. Metode Penelitian dalam Psikologi. Jakarta: Salemba Humanika.

[6] Gerk, Laura E. 2012. Development Through The Lifespan - Dari Dewasa Awal Sampai Menjelang Ajal. Yogyakarta: Pustaka Pelajar.

[7] Gerk, Laura E. 2012. Development Through The Lifespan - Dari Prenatal 
Sampai Remaja. Yogyakarta: Pustaka Pelajar.

[8] Gregory J.R. 2010. Tes Psikologi, Sejarah, Prinsip, dan Aplikasi. Terjemahan Jakarta: Penerbit, Erlangga.

[9] Kaplan, Robert M., Saccuzzo, Dennis P. 2012. Pengukuran Psikologi - Prinsip, Penerapan, dan Isu. Jakarta: Salemba Humanika.

[10] King, Laura A. 2016. Psikologi Umum Sebuah Pandangan Apresiatif. Buku 1 Edisi 3. Jakarta: Salemba Humanika.

[11] Papalia, Diane E., Feldman, Ruth Duskin. 2014. Menyelami Perkembangan Manusia. Terjemahan. Buku 1 Edisi 12. Jakarta: Salemba Humanika.

[12] Papalia, Diane E., Feldma, Ruth Duskin. 2014. Menyelami Perkembangan Manusia. Terjemahan. Buku 2 Edisi 12. Jakarta: Salemba Humanika.

[13] Papalia, Olds, Feldman. 2009. Human Development. Terjemahan. Buku 1 Edisi 10. Jakarta: Salemba Humanika.

[14] Papalia, Olds, Feldman. 2009. Human Development. Terjemahan. Buku 2 Edisi 10. Jakarta: Salemba Humanika.

[15] Prawitasari J.E. 2012. Psikologi Terapan. Melintas Batas Disiplin Ilmu. Jakarta: Penerbit Erlangga
[16] Roediger H.L. Kantowitz B.H.Elmes D.G. 2014. Metode Penelitian Dalam Psikologi.

[17] Sarjono, Haryadi, Julianita, Winda. 2011. SPSS vs Lisrel - Sebuah Pengantar, Aplikasi untuk Riset. Jakarta: Salemba Humanika.

[18] Santrock, John W. 2011. Masa Perkembangan Anak. Buku 1 Edisi 11. Jakarta: Salemba Humanika.

[19] Santrock, John W. 2011. Masa Perkembangan Anak. Buku 2 Edisi 11. Jakarta: Salemba Humanika.

[20] Santrock, John W. 2011. Psikologi Pendidikan. Edisi Kedua. Jakarta: Kencana.

[21] Santrock,J,W. 2002 Life- Span Development. Terjemahan. Jakarta: PT Rajawali

[22] Santrock, John W. 2002. Life-Span Development. Edisi 13 Jilid 2. Jakarta: Erlangga.

[23] Supranto. 2008. Statistik Teori dan Aplikasi. Edisi Ketujuh Jilid 1. Jakarta: Erlangga.

[24] Sarwono .S. Menarno.E.A. 2014. Psikologi Sosial. Jakarta: Penerbit Salemba Humanika 